\title{
ATTENUATED TOTAL REFLECTION FOURIER TRANSFORM INFRARED (ATR-FTIR): A METHOD FOR THE BIOCHEMICAL STUDY OF WALNUT LEAVES
}

\author{
Carmen Mihaela Topală ${ }^{1, *}$, Loredana Elena Vîjan ${ }^{1}$, Simona Giura ${ }^{2,3}$, Mihai Botu ${ }^{2,4}$ \\ ${ }^{1}$ University of Piteşti, Faculty of Sciences, Physical Education and Computer Science, \\ Department of Natural Sciences, 1 Targul din Vale Street, Pitesti, Argeş, RO 110142, Romania \\ ${ }^{2}$ University of Craiova - Fruit Growing Research and Extension Station (UCv-SCDP.) Vâlcea, \\ 464 Calea lui Traian Street, Rm. Vâlcea, RO 240371, Romania \\ ${ }^{3}$ University of Craiova, Horticulture Faculty, Doctoral School of Plant and Animal Resources Engineering, \\ 13 A.I. Cuza Street, Craiova, Dolj, RO 200396, Romania \\ ${ }^{4}$ University of Craiova, Faculty of Horticulture, Department of Horticulture and Food Science, \\ 13 A.I. Cuza Street, Craiova, Dolj, RO 200585, Romania
}

\begin{abstract}
ATR-FTIR spectra appear to function as biochemical fingerprints unique to each species and is used in our study to characterize eight walnut cultivars with different geographic origins and different agro-biological characteristics. Leaves were collected from four Romanian cultivars ('Verisval', 'Valrex', 'Germisara', 'Jupâneşti'), three American ('Serr', 'Payne' and 'Vina') and one French cultivar ('Franquette') and were analysed using ATR-FTIR Spectroscopy combined with multivariate data analysis (PCA). 'Franquette' variety separates from the rest of the cultivars (Romanian and American). Analysis of PCA loadings identifies the specific spectral regions: $3000-2800 \mathrm{~cm}^{-1}, 1750$ $1600 \mathrm{~cm}^{-1}$ and 1250-1200 $\mathrm{cm}^{-1}$, which are responsible for these differences in walnut leaves. No further sample preparation is required for ATR-FTIR and the measurement time of less than 1 min per sample will come more frequently method for analysing the biochemical composition of biological material, as well as a further tool for discrimination of walnut cultivars.
\end{abstract}

Keywords: ATR-FTIR, biochemical constituents, walnut leaves

\section{INTRODUCTION}

The common walnut (Juglans regia L.), known as English, Persian and Carpathian walnut, is an important nut crop and medicinal plant with different properties that is considered less, despite having great therapeutic potential in the traditional medicine. The use of walnuts in traditional medicine and review of experimental studies demonstrated the presence of multiple, effective, and useful compounds which may provide the opportunity for the production of lipid-lowering, antidiabetes, and liver protective drugs (Delaviz, 2017).

Walnut and by-products derived from the walnut tree contains flavonoids, phospholipids, sterols, triterpenes, quinones, oils, tannins, essential fatty acids (Fukuda et al., 2003; Amaral et al., 2004; 
Stampar et al., 2006; Li et al., 2007; Pereira et al., 2008; Cosmulescu et al., 2014; Kafkas et al., 2017).

Phenolic compounds such as pyrogallol, p-hydroxybenzoic acid, vanillic acid, ethyl gallate, protocatechuic acid, tannic acid, syringic acid, gallic acid, ferulic acid, trans-cinnamic acid, o-coumaric acid, p-coumaric acid, chlorogenic acid, and caffeic acid were also isolated from walnuts. Walnut has also polyphenols, with antioxidant activity so protective that it is described as "remarkable". Free fatty acids, diglycerides, sterols, sterol esters, phosphatides and vitamins are present in minor quantities in walnut. Due to composition of the fruit, the walnut is classified as a strategic nut crop for human nutrition and is included in the FAO list of priority plants (Gandev, 2007).

Our previous studies described polyphenols, flavonoids, and tannins content in walnut leaves, green walnut husk and fruit during growing season (Giura et al., 2019; Bizera et al., 2019).

Attenuated Total Reflectance (ATR) is today the most widely used FTIR sampling tool for the chemical analysis of biological samples. ATR generally allows qualitative or quantitative analysis of samples with little or no sample preparation. It is an efficient technique for analyzing functional group of organic substances for identify structure of compounds, providing a comprehensive biochemical fingerprint of the analysed sample (Griffiths, 1978; Baker et al., 2014). Thereby, FTIR uses the vibrational characteristics within molecules to obtain a fingerprint spectrum with features defined by the functional chemical groups within the sample. Each biological material presents unique spectrum signals. Attenuated total reflectance (ATR) spectra of plant leaves display complex absorption features related to organic constituents of leaf surfaces.

Leaves are complex assemblages of organic compounds and it might be expected that they would display distinctive spectral features in the infrared range $\left(4000-400 \mathrm{~cm}^{-1}\right)$. Fundamental vibration modes of various molecular functional groups produce characteristic spectral absorption features that can serve to fingerprint many compounds (Silverstein and Webster, 1998).

In contrast to the more widely used near-infrared (NIR) region, where absorption bands represent the overtones, the mid-infrared is the region of fundamental molecular vibrations (Smith 1979); consequently, the absorbance band are less overlapped and better distinguished in the mid than NIR spectral ranges. In the last decade, ATR-FTIR spectroscopy was successfully applied to the taxonomical discrimination of plant species, demonstrating its reliability to probe plant chemical composition as a species trait (Kim et al., 2004; Rana et al., 2008; Rana et al., 2018).

The goal of our work was to investigate the use of ATR-FTIR spectroscopy for the direct qualitative analysis of the chemical composition of fresh green intact leaves of walnut and including the effect of different varieties on biochemical composition and to explore the possibility to apply FTIR spectral as fingerprint of walnut substances found in each cultivar. Different walnut varieties can be discriminated by pattern of FTIR spectra of leaves. The information could be kept as reference materials for prompt identification in case of different walnut cvs.

Infrared spectrum for a biological system includes lipids, carbohydrates and proteins, in a simplified pattern and is shown in the figure 1, with typical IR absorbance positions (protein amide I: 1690 $1600 \mathrm{~cm}^{-1}$ and amide II: $1575-1480 \mathrm{~cm}^{-1}$, lipid $=\mathrm{CH}_{2}: 3100-3000 \mathrm{~cm}^{-1}$ and $\mathrm{CH}_{2}, \mathrm{CH}_{3}: 3000-$ $2850 \mathrm{~cm}^{-1}$, carbohydrates: $1130-960 \mathrm{~cm}^{-1}$ )

The infrared spectra of protein are characterized by a set of absorption regions known as the amide region and the $\mathrm{C}-\mathrm{H}$ region. The amide $\mathrm{I}$ band arises principally from the $\mathrm{C}=\mathrm{O}$ stretching vibration of the peptide group. The amide II band is primarily $\mathrm{N}-\mathrm{H}$ bending with a contribution from $\mathrm{C}-\mathrm{N}$ stretching vibrations (Mantsch and Chapman, 1996). 


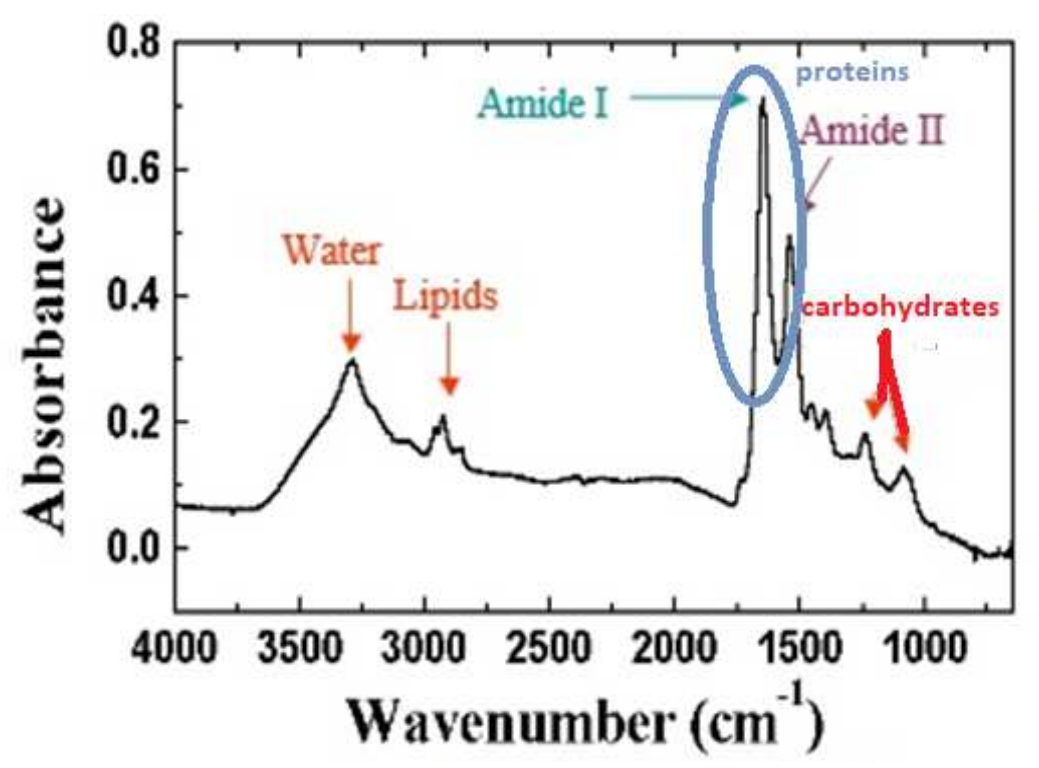

Figure 1. Infrared spectrum of a biological system (Mantsch and Chapman, 1996)

\section{MATERIALS AND METHODS}

\section{Plant material and sampling}

The walnut leaves were collected from UCv-SCDP Vâlcea germplasm collection during summer of 2019 from eight cultivars: four Romanian ones ('Verisval', 'Valrex', 'Germisara', 'Jupâneşti'), three American ('Serr', 'Payne' and 'Vina') and one French cultivar ('Franquette').

\section{Sample preparation and ATR-FTIR spectra acquisition}

ATR-FTIR spectra for both background and leaf measurements were recorded at a resolution of 4 $\mathrm{cm}^{-1}$ and 100 scans in the range of $600-4000 \mathrm{~cm}^{-1}$, detector TGS, apodization Cosine. The recording was done with the FTIR Jasco 6400 spectrometer equipped with an ATR accessory with a diamond crystal (Pike Technologies). Background scanning and correction was carried out regularly after $15 \mathrm{~min}$. Each spectrum was calculated as an average of five successive measurements to minimize measurement error. The spectral data were processed with JASCO Spectra Manager II software. IR bands were identified by comparison with published assignments in different leaves (Wang and Griffith, 1985; Rana et. al., 2018; Topală et. al., 2019; Topală and Rusea, 2019).

\section{Data Analysis}

Infrared Spectra were exported from Spectra Manager, in ASCII (dx) format, into the Unscrambler Software (Edition X 10.4, Camo. Oslo Norway) for chemometric analysis. Spectra were preprocessed using the second-derivative transformation, the Savitzky-Golay derivation. The use of spectra derivatives with Savitzky-Golay algorithm as a chemometric pre-processing technique is widely reported in most classification based on FTIR spectroscopy (Chatfield and Colins, 1980; Jolliffe, 1986; Topală et. al, 2017; Topală and Tătaru, 2018; Topală et. al, 2019). The principal component analysis (PCA) model was developed using cross validation. PCA was performed both on the entire spectral range (4000 to $400 \mathrm{~cm}^{-1}$ ), and on the MIR 'fingerprint' (1750 to $700 \mathrm{~cm}^{-1}$ ). 


\section{Current Trends in Natural Sciences}

Vol. 9, Issue 17, pp. 266-272, 2020

https://doi.org/10.47068/ctns.2020.v9i17.033

Current Trends in Natural Sciences (on-line)

ISSN: 2284-953X

Current Trends in Natural Sciences (CD-Rom)

ISSN: 2284-9521

ISSN-L: 2284-9521

ISSN-L: 2284-9521

\section{RESULTS AND DISCUSSIONS}

Leaf surfaces are composed of many organic compounds and produce complex spectra showing many absorption bands.

At the present level of understanding it is not possible to identify all of the specific compounds responsible for every spectral feature. However, it is possible to identify major classes of compounds and to recognize whether a particular class is especially abundant in a particular leaf sample (Ribeiro da Luz, 2006; Topală et. al., 2019).

The FTIR spectra of leaves from eight walnut cultivars are shown in figure 2 and preliminary assignments are present in table 1.

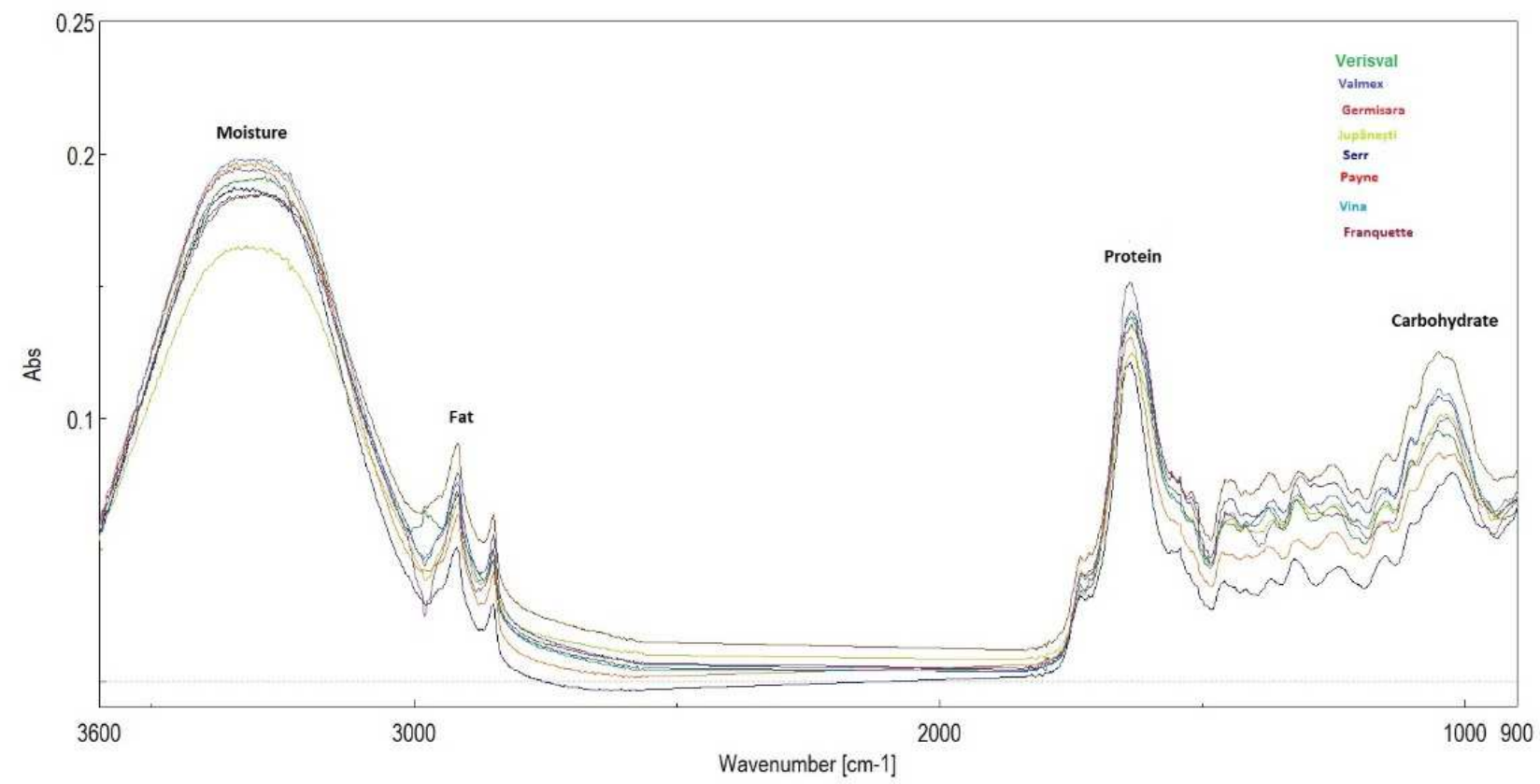

Figure 2. ATR-FTIR spectra of eight walnut leaf samples with mean biochemical regions (protein: amide I: 16901600 and amide II: $1575-1480$, lipid $=\mathrm{CH}_{2}: 3100-3000$ and $\mathrm{CH}_{2}, \mathrm{CH}_{3}: 3000-2850$, carbohydrates: $1130-960 \mathrm{~cm}^{-1}$ ).

Table 1. The Preliminary Assignment of the Walnut Cultivars' Leaves

\begin{tabular}{|c|c|c|c|c|c|c|c|c|}
\hline \multicolumn{8}{|c|}{ Frequencies $\left(\mathrm{cm}^{-1}\right)$} & \\
\hline $\begin{array}{l}\text { 'Verisval' } \\
\text { (1) }\end{array}$ & $\begin{array}{c}\text { 'Valrex' } \\
\text { (2) }\end{array}$ & $\begin{array}{c}\text { 'Germisara' } \\
\text { (3) }\end{array}$ & $\begin{array}{c}\text { 'Jupâneşti' } \\
\text { (4) }\end{array}$ & $\begin{array}{l}\text { 'Serr' } \\
(5)\end{array}$ & $\begin{array}{c}\text { 'Payne' } \\
\text { (6) }\end{array}$ & $\begin{array}{c}\text { 'Vina' } \\
\text { (7) }\end{array}$ & $\begin{array}{c}\text { 'Franquette' } \\
\text { (8) }\end{array}$ & Assignment \\
\hline 3285.14 & 3343.96 & 3283.21 & 3320.82 & 3291.89 & 3298.64 & 3340.1 & 3341.07 & $v(\mathrm{OH}, \mathrm{NH})$ \\
\hline 2917.77 & 2919.7 & 2917.77 & 2917.77 & 2917.77 & 2917.77 & 2918.73 & 2918.73 & $\mathrm{v}_{\mathrm{as}}(\mathrm{C}-\mathrm{H})$ \\
\hline 2850.27 & 2850.27 & 2850.27 & 2849.31 & 2849.31 & 2849.31 & 2850.27 & 2850.27 & $\mathrm{~V}_{\mathrm{s}}(\mathrm{C}-\mathrm{H})$ \\
\hline 1636.3 & 1636.3 & 1635.34 & 1634.38 & 1635.34 & 1636.3 & 1634.38 & 1636.3 & $v(\mathrm{C}=\mathrm{O})$ Amide I \\
\hline 1051.98 & 1023.05 & 1050.05 & 1034.62 & 1050.05 & 1050.05 & 1049.09 & 1033.66 & $v(\mathrm{C}-\mathrm{O})$ \\
\hline
\end{tabular}

The FTIR spectrum of walnut leaves (table 1, figure 2) is characterized by distinct aliphatic bands in the aliphatic stretching region $2800-3000 \mathrm{~cm}^{-1}$ from lipids, distinct oxygenated groups at 1600 $1800 \mathrm{~cm}^{-1}$ from proteins and at approximately $1050 \mathrm{~cm}^{-1}$ attributed to C-O from carbohydrates. 
FTIR spectra derived from biological material (e.g., whole cells) typically present superimposed spectra of individual chemical components, which can be difficult to deconvolute. Multivariate data analysis is a powerful tool for the interpretation of these complex spectral data and allows prediction of the chemical composition in the sample by reducing its dimensionality (Topală et.al, 2019). In principal component analysis (PCA), the maximal variation of the data is identified along principal components (latent variables), which can be used to detect spectral (and thus chemical) differences between samples. Analysis of PCA loadings identifies the specific spectral regions responsible for these differences (Mariey et. al. 2001; Ringnér, 2008).
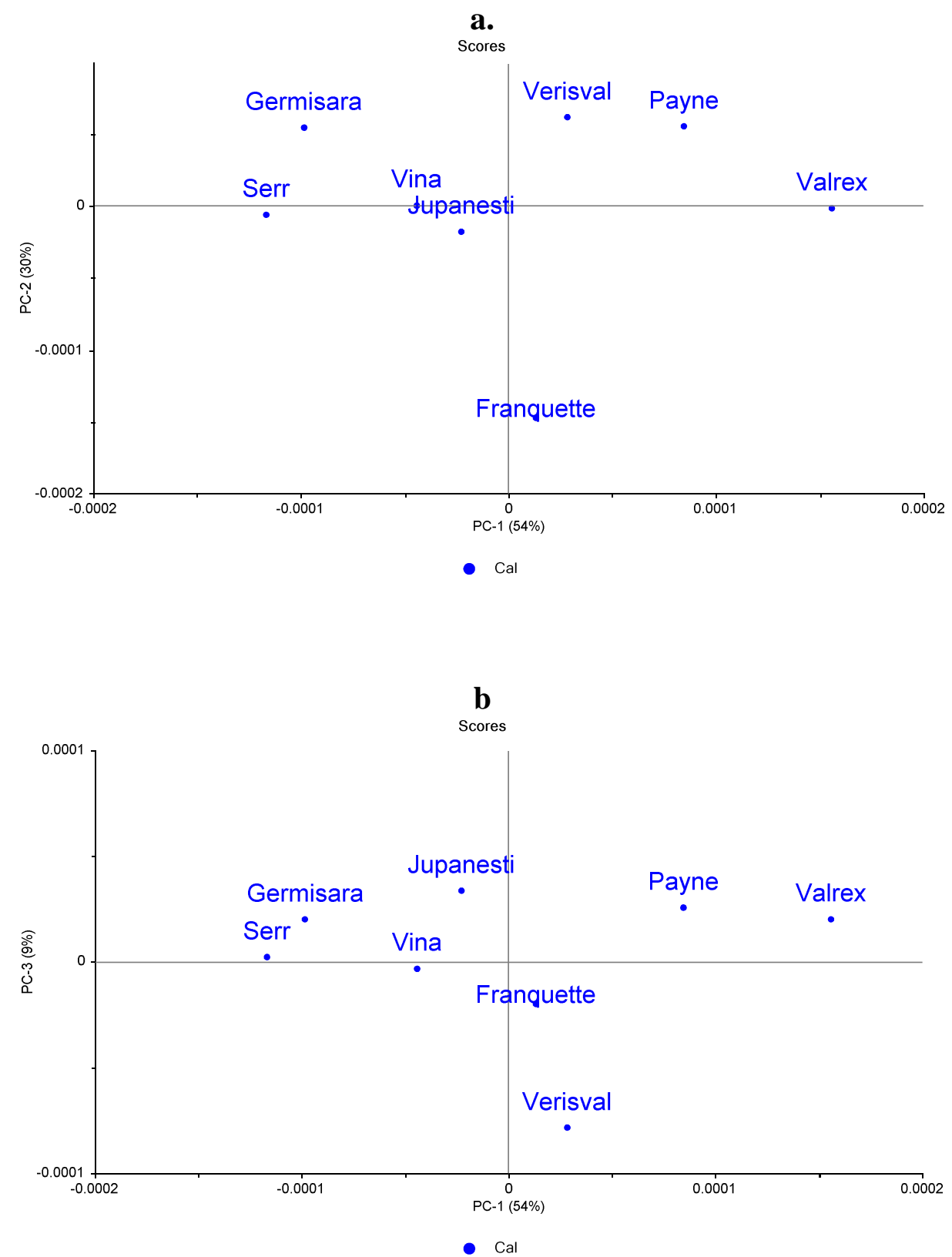

Figure 3. 2-D scores obtained from PCA of FTIR spectra of walnut leaves for the first two PCs a), and PC3 versus PC1 b) 
Principal Component Analysis (PCA) (Martens and Naes, 1989) is a method used to extract the systematic variations from a data set. PCA reduces the dimensionality of data with a minimum loss of information. The main systematic variation in the data set is given by the principal component, PC. The common characteristics of all spectra are modelled in one or several PC. Plotting two PCs relatively to each other affords an analysis of the interaction between two PCs, thanks to the similarities or differences between samples (Esbensen et al., 2002; Kumar, 2014). In matrix representation, the model with a given number of components has the following equation:

$$
X=T \cdot P^{T}+E
$$

where $T$ is the scores matrix, $P$ the loadings matrix and $E$ the error matrix.

The PCA were performed with Unscrambler software (Dupuy et al., 2016).

For the selected regions (lipids, proteins and carbohydrates): $3000-2800 \mathrm{~cm}^{-1}, 1750-1600 \mathrm{~cm}^{-1}$ and $1250-1200 \mathrm{~cm}^{-1}$, the results of PCA analysis are presents in figure 3 .

For the walnut leaves considered, the first three principal components (PCs) represent $93 \%$ of the total variance $(\mathrm{PC} 1=54 \%, \mathrm{PC} 2=30 \%$ and $\mathrm{PC} 3=9 \%)$. This indicates that these three components were sufficient to provide a good separation between the groups. 'Franquette' separates from the rest of the cultivars analysed (Romanian and American).

\section{CONCLUSIONS}

Total Reflection Fourier Transform Mid-Infrared (ATR-FTIR) spectroscopy, a fast and costeffective tool requiring minimal sample preparation, to investigate the response of leaf chemical composition.

In conclusion, we suggest that ATR-FTIR, as a rapid and low-cost approach, represents a reliable option to complement or replace more expensive and laborious biochemical analyses and it can be applied as additional tool to discriminate the cultivars.

\section{REFERENCES}

Amaral, J.S., Seabra, R.M., Andrade, P.B., Valentão, P., Pereira, J.A., Ferreres, F. (2004). Phenolic Profile in the Quality Control of Walnut (Juglans regia L.) Leaves. Food Chemistry, 88(3), 373-379.

Baker, M.J., Trevisan, J., Bassan, P., Bhargava, R., Butler, H.J., Dorling, K.M., Fielden, P.R., Fogarty, S.W., Fullwood, N.J., Heys, K.A., Hughes, C., Lasch, P., Martin-Hirsch, P.L., Obinaju, B., Sockalingum, G.D., Sulé-Suso, J., Strong, R.J., Walsh, M.J., Wood, B.R., Gardner, P., Martin, F.L. (2014). Using Fourier Transform IR Spectroscopy to Analyze Biological Materials. Nat. Protoc, 9, 1771-1791.

Bizera, M., Giura, S., Scutelnicu, A., Preda, S., Botu, M., Vijan, L.E. (2019). Physico-Chemical Characterization of some Walnut Fruits Collected in 2018 from University of Craiova - S.C.D.P. Vâlcea, România. Current Trends in Natural Sciences, 8(15), 169-178.

Chatfield, C., Colins, A.J. (1980). Introduction to Multivariante Analysis, Chapman \&Hall, London.

Cosmulescu, S., Botu, M., Achim, G., Baciu, A., Gruia, M., Trandafir, I. (2014). Polyphenol Content in Walnut (Juglans regia L.) Mature Leaves. Acta Horticulturae, 1050, 205-212.

Delaviz, H., Mohammadi, J., Ghalamfarsa, G., Mohammadi, B., Farhadi, N. (2017). A Review Study on Phytochemistry and Pharmacology Applications of Juglans regia. Plant. Pharmacogn Rev, 11(22), 145-152.

Dupuy, N., Gaston, F., Marque, S.R.A., Barbaroux, M., Dorey, S. (2016). FTIR study of ageing of gamma-irradiated biopharmaceutical EVA based film. Polymer Degradation and Stability, 129, 19-25.

Esbensen, K. H., Guyot, D., Westad, F., Houmoller, L.P. (2002). Multivariate Data Analysis: in Practice: an Introduction to Multivariate Data Analysis and Experimental Design.

Fukuda, T, Ito, H, Yoshida, T. (2003). Antioxidative Polyphenols from Walnuts (Juglans regia L.). Phytochemistry, 63(7), 795-801.

Gandev, S. (2007). Budding and Grafting of the Walnut (Juglans regia L.) and their Effectiveness in Bulgaria. Bulgarian Journal of Agricultural Science, 13(6), 683-689. 


\section{Current Trends in Natural Sciences}

Vol. 9, Issue 17, pp. 266-272, 2020

https://doi.org/10.47068/ctns.2020.v9i17.033

Current Trends in Natural Sciences (on-line)

ISSN: 2284-953X

Current Trends in Natural Sciences (CD-Rom)

ISSN: 2284-9521

ISSN-L: 2284-9521

ISSN-L: 2284-9521

Giura, S., Botu, M., Vulpe, M., Vîjan, L.E., Mitrea, R. (2019). Evolution of Polyphenols, Flavonoids, and Tannins Content in Walnut Leaves and Green Walnut Husk during Growing Season. Not Bot Horti Agrobo, 47(4), 12641271.

Griffiths, P.R. (1978). Fourier Transform Infrared Spectrometry: Theory and Instrumentation. In: Griffiths, P.R. (Ed.), Transform Techniques in Chemistry. Plenum Publishing Corporation, New York, 109-139.

Jolliffe, I.T., Principal Component Analysis. 1986. Springer-Verlag, New York, 1st Ed.

Kafkas, E., Burguta, Ozcan, H., Ozcan, A., Sutyemez, M., Kafkas, S., Türemis, N. (2017). Fatty Acid, Total Phenol and Tocopherol Profiles of some Walnut Cultivars: A Comparative Study. Food And Nutrition Sciences, 8(12), 10741084.

Kim, S.W., Ban, S.H., Chung, H., Cho, S., Chung, H.J., Choi, P.S., Yoo, O.J., Liu, J.R. (2004). Taxonomic Discrimination of Flowering Plants by Multivariate Analysis of Fourier Transform Infrared Spectroscopy Data. Plant Cell Rep. Physiol. Biochem, 23, 246-250.

Kumar, Bansal, A., Sarma, G.S., Rawal, P.K. (2014). Chemometrics Tools used in Analytical Chemistry: an overview, Talanta, 123, 186-199.

Li, L., Tsao, R., Yang, R., Kramer, J.K.G., Hernandez, M. (2007). Fatty Acid Profiles, Tocopherol Contents, and Antioxidant Activities of Heartnut (Juglans ailanthiofolia var. cordiformis) and Persian Walnut (Juglans regia L.). Journal of Agricultural and Food Chemistry, 55(4), 1164-1169.

Mantsch, H.H., Chapman, D. (1996). Infrared Spectroscopy of Biomolecules, 1st Ed., New-York: Wiley-Liss

Mariey L., Signolle J., Amiel C., Travert J. (2001). Discrimination, Classification, Identification of Microorganisms using FTIR Spectroscopy and Chemometrics. Vib. Spectrosc. 26, 151-159.

Martens, H., Naes, T. Multivariative Calibration, Wiley, 1989.

Pereira, J.A., Oliveira, I., Sousa, A., Ferreira, I.C.F.R., Bento, A., Estevinho, L. (2008). Bioactive Properties and Chemical Composition of Six Walnut (Juglans regia L.) Cultivars. Food and Chemical Toxicology, 46(6), 21032111.

Rana, R., Herz, K., Bruelheide, H., Dietz, S., Haider, S., Jandt, U., Pena, R. (2018). Leaf Attenuated Total Reflection Fourier Transform Infrared (ATR-FTIR) Biochemical Profile of Grassland Plant Species Related to Land-Use Intensity. Ecological Indicators, 84, 803-810.

Rana, R., Müller, G., Naumann, A., Andrea Polle, A., 2008. FTIR Spectroscopy in Combination with Principal Component Analysis or Cluster Analysis as a Tool to Distinguish Beech (Fagus sylvatica L.) Trees Grown at Different Sites. Holzforschung, 62, 530-538.

Ribeiro Da Luz, B. (2006). Attenuated Total Reflectance Spectroscopy of Plant Leaves: A Tool for Ecological and Botanical Studies. New Phytologist, 172, 305-318.

Ringnér M. (2008). What Is Principal Component Analysis? Nat. Biotechnol. 26, 303-304.

Silverstein, R.M, Webster, F.X. (1998). Spectrometric Identification of Organic Compounds. 6th Edn. New York, NY, USA: John Wiley \& Sons, 71-143.

Smith, A.L. (1979). Applied Infrared Spectroscopy-Fundamentals, Techniques, and Analytical Problem-Solving. John Wiley \& Sons, New York.

Stampar, F., Solar, A., Hudina, M., Veberic, R., Colaric, M. (2006). Traditional Walnut Liqueur - Cocktail of Phenolics. Food Chemistry, 95(4), 627-631.

Topală, C.M., Păunescu, A., Soare, L.C. (2019). ATR - FTIR Spectral Analysis of Ferns Using as Fingerprint for Identification of Fern Species. Rev. Chim. (Bucharest), 70(3), 875-880.

Topală, C.M., Rusea, I. (2018) Analysis of Leaves Using FTIR Spectroscopy and Principal Component Analysis Discrimination of Different Plant Samples. Current Trends in Natural Sciences, 7(13), 286-291.

Topală, C.M., Tătaru, L.D. (2018). Rapid Method for the Discrimination of Romanian Wines based on Mid-Infrared Spectroscopy and Chemometrics, Rev. Chim. (Bucharest), 2, 469-473.

Topală, C.M., Tătaru, L.D., Buciumeanu, E.C., Guță, I.C. (2017). FTIR Spectra of Grapevines (Vitis vinifera L.) in the Presence of Virus Infections", Acta Hortic. 213-318

Wang, S.H., Griffith, P.R. (1985). Resolution Enhancement of Reflectance IR Spectra of Coals by Fourier-SelfDeconvolution: 1. C-H Stretching and Bending Modes. Fuel, 64, 229-236. 